\title{
Understanding Organizational Commitment and Satisfaction among Scout Volunteers
}

\author{
Yeni Rahmawati \\ Faculty of Educational Studies, Universiti Putra Malaysia \\ 43400 UPM, Serdang, Selangor, Malaysia \\ E-mail: yeni_kenshin@yahoo.com
}

Norhasni Zainal Abiddin (Corresponding author)

Faculty of Educational Studies, Universiti Putra Malaysia

43400 UPM, Serdang, Selangor, Malaysia

E-mail: nonie@upm.edu.my

Ihsan Ro'is

Faculty of Economic Studies, Universitas Mataram

Jalan Majapahit 62, Mataram NTB, Indonesia

E-mail: drihsanrois@gmail.com

Received: August 5, 2014 Accepted: September 5, 2014 Published: September 12, 2014

doi:10.5296/ire.v2i2.6305 URL: http://dx.doi.org/10.5296/ire.v2i2.6305

\begin{abstract}
Organizational commitment considered as the important issue in any types of organization. Majority studies have been addressed on organizational commitment among profit worker. Oppositely, studies about organizational commitment addressed for volunteer to run the program generally engage with nonprofit organization tend to be lack. This study was conducted to emerge organizational commitment in different aspect within nonprofit organization especially related to non-formal education as well as extension education. The objective of the study is to examine relationship between satisfaction and organizational commitment among scout volunteer. The research used quantitative method to analyze the data. The instrument to collect the data used questionnaire adapted from previous studies. It
\end{abstract}


was divided into several parts: demographic information, Volunteer Satisfaction Index (VSI), and Organizational commitment (OCQ). By using simple random sampling technique, the questionnaire was administered to 220 respondents from scout center organization in Samarinda-East Kalimantan, Indonesia. Only 207 samples (94\%) could be applied for data analysis whereby the rest were considered incomplete answer. The data was analyzed through descriptive as well as inferential statistic. The finding of the study revealed that two of four dimensions from job satisfaction namely organizational support and group integration considered having correlation towards organizational commitment, conversely, organizational efficacy and empowerment were failed to have correlation with organizational commitment. Several implications and recommendation related to the subject were provided in this study.

Keywords: Non-formal education, organizational commitment, satisfaction, scout volunteer

\section{Introduction}

Generally, volunteer is an activity performed with intention to help others and without expectation of monetary or material compensation (Harootyan, 1996; Okun \& Schultz, 2003). Related to this study, volunteer have been discussed as preliminary from two aspects precisely from non formal education (NFE) and nonprofit organization (NPO). NFE is having similar function with extension education that is providing activities outside formal institution. According to Merriam and Cafarrella (1999), NFE is the opposite of formal education likewise school institution, otherwise, NFE tends to be community learning which provide several knowledge that cannot be obtained in school area. $4 \mathrm{H}$ activities for youth (Terry, Harder, \& Pracht, 2011) or other youth organization such as scouting (Vaske, 2008) are several example of NFE. As regard to NFE, the existence of volunteer involvement almost cannot be separated to NFE as well as NPO especially that concern on educational program. For instance, it was known that majority literacy program involved many volunteers in it (Schmiesing, Soder, \& Russell, 2005). Volunteer is having role as the organizer, program developer and partner offering attention out of educational institution. Moreover, volunteer can be identified as mentor and provider within NFE experiences especially for youth (Terry et al., 2011). Meanwhile, from the nonprofit view, volunteers can be seen as an essential foundation of many nonprofit organizations (Terry et al., 2011). Volunteer is denoted as unpaid worker who contribute their time to organization or group (Snyder \& Omoto, 2004). On the other words, volunteer engaged with organization and voluntarily share their interest without expecting any material funding. As regards to that purpose, both of those aspects are having similarity in social caring that is constantly having contribution for the development of society.

As a matter of fact, Chacon, Vecina, and Davila (2007) revealed that factually volunteer deny working independently, they work within organizational context. Volunteer could not improve the society alone, they need leader to direct their effort to solve specific problem (Boyd, 2003). Therefore, generally they engaged themselves within organization to provide direct as well as indirect service to the community as well as the organization (Hartenian, 2007). Direct service means service that is given directly such as officer for sport event, helping victim of natural disaster, tutoring illiterate, AIDS volunteer, youth and adult partner learning. 
Meanwhile, indirect service is included involvement and their relation within organization and other volunteers. Moreover, volunteer plays distinct roles in organizations as well as in larger community especially related to nonprofit organization and public agencies (Cnaan \& Goldberg-Glen, 1991). From that argument, it can be seen that volunteer has a different job types compared with others worker in term of responsibility to society. In addition, nonprofit organization has valuable assets which not existed in profit organization precisely committed and enthusiastic volunteer (Bang, Ross, \& Reio, 2013). Volunteer works in order to fulfill the needs of being involved rather than earning compensation. This pointed out that the presence of volunteer is extremely has been acknowledged by the society. As regards to direct and indirect service, it cannot be denied that both of those characteristics are dependable. In fact, during providing services to the society, they considered provides their service to organization. For that matter, commitment is having essential factor within organization since it affect on how long the volunteer will provide their services. Therefore, the viability of a nonprofit organization is able to be identified by their commitment within organization. Therefore, organizational commitment is fundamentally required for NPO to maintain the life of organization.

Indeed, the energy which ties individual for relevance achievement to their specific goal can be mentioned as commitment (Meyer \& Herscovitch, 2001). Meanwhile, organizational commitment defined as relationship between organization and individual (Mathieu \& Zajac, 1990). Moreover, Mowday, Steers, and Porter (1979) explained that organizational commitment is the strength to identify the individual within their involvement in specific organization. For that matter, several researches were concern on this element and majority of it was focused and intentionally have been purposed for paid worker in profit sector. Further, since several studies prefer to compensated sector, few studies concern on organizational commitment within volunteer in nonprofit organization (Davila \& Cachon, 2003; Pearce, 1993).

In fact, organization requires committed employees and required workforce from employee since it leads essential result for example reduce the turnover (Phillips \& Edwards, 2008). Commitment is defined as attitude (Mowday et al., 1979). Attitudinal commitment emerge when individual and their organization linkage each other (Sheldon, 1971). Therefore, Mowday's approach intends to represent attitudinal rather than behavioral which related to social cognitive theory. Further, attitude symbolize for something further than passive loyalty, thus it requires active involvement and action within organization such as provide something likewise contribute their time for organization. In other words, commitment is not merely from the passive loyalty even, real action is required (Dorsch et al., 2002). In contrast, behavioral commitment intends to shape their environment through their behavior rather than reacting to it. However, Meyer and Allen (1997) found relation between Mowday's approach and affective commitment whereby affective commitment engaged with behavioral character. In brief, it cannot be deprived of that there would be any interrelationship between attitude and behavior within organizational commitment behind Mowday's approach.

Four factors influence organizational commitment precisely personal factors, structural and role related characteristic, and work experience (Steers, 1977). Moreover, motivation is 
included in personal factors while satisfaction tends to be influenced by work experience. As regards to the uniqueness of volunteer characteristic related to their involvement within organization as well as factor that affected their commitment to organization, the current study also gives emphasis on job satisfaction. If motivation tend to be discussed as personal needs, satisfaction is concerning in organizational needs. Satisfaction is referred as affective reactions to facet of the condition (Smith, Kendall, \& Hulin, 1969). Furthermore, job satisfaction is leveled as main concept within organizational psychology and work which is used as agent link between working condition and organizational, and personality outcomes (Warsi, Fatima, \& Sahibzada, 2009). Therefore, satisfaction in general context meant as a facet of work in human services. While in profit worker, the essential aspect of satisfaction is in attention to pay, benefit, and promotion (Williamson, 1996). Meanwhile, it is vastly different psychological existed in volunteer environment since satisfaction within volunteer tend to be affected by need, social responsibility, not concerning on monetary, and merely for obligation (Ellis \& Noyes, 1990).

Considering those issues, theory hierarchy of need by Maslow become widely referred to job satisfaction besides it contributed to motivation. According to two factors theory by Herzberg, job satisfaction is affected by intrinsic reward which included as motive while from volunteer perspective, intrinsic rewards increase the satisfaction. Therefore, that is become the reason people intent to continuing their services since they satisfy what they obtain from the experience and value the rewards receive and willing to sustain and extend (Gidron, 1983). Consequently, satisfaction is actually giving wide impact differently from motivation towards organizational commitment since it can enlarge the organizational devotion and better performance. Further, in the current study addressed job satisfaction index by Galindo-Kuhn and Guzley (2001) to measure the facets of satisfaction. There are four dimension included namely organizational support, participation efficacy, empowerment, and group integration (Galindo-Kuhn \& Guzley, 2001).

Organizational support is able to emerge feeling of satisfying within volunteer. For instance encouragement and training that has been conducted emerging volunteer satisfaction from emotional and educational to perform their assignment (Cyr \& Dowrick, 1991; Ozminkowski, Supiano, \& Campbell, 1991). Meanwhile, participation efficacy is factor that affecting job satisfaction among volunteer (Gidron, 1983). From this factor, volunteer has satisfaction since they feel other people will get benefit from their services. Meanwhille, empowerment is reflection from role assignment and communication quality whereby it related to satisfying of a chance to utilize their skills and knowledge. Further, according this factor, volunteer feel satisfy since they have good access to have information within organization and they have freedom in deciding the volunteer assignment. In addition, group integration become one dimension of satisfaction since based on this integration volunteer would be able to have contact with another staff or volunteer involved. For instance, volunteer wanted to get new activity since they can make new contact with other volunteer (Field \& Johnson, 1993).

Furthermore, study from Galindo-Kuhn and Guzley (2001) has been used as the reference in the study although the approach being classified as new (Ping, Wing, Chui, \& Yuen, 2011). Based on the result of correlation between VSI and intent to remain (Galindo-Kuhn \& Guzley, 
2001) it was found that overall dimension had positive relationship. By using similar content of VSI from previous study, Ping et al. (2011) found that overall dimension of VSI reported having positive correlation with functional motivation in Chinese context. Meanwhile, Siti-nazilah, Rozmi, and Fauziah (2012) used job descriptive index (leadership, co-volunteer, task, and position opportunities) to measure volunteer satisfaction in their study within college volunteer universities in Peninsular Malaysia. Moreover, they found that there was a relationship between overall satisfaction and organizational commitment. For comparison, study in profit organization (Warsi et al., 2009) found similar finding. Based on their study, overall job satisfaction has higher relationship with organizational commitment prefer to the relationship between work motivation and organizational commitment.

After several literatures review from previous studies in different context has been discussed and after looking at the gap between profit and nonprofit organization, the current study was purposed generally to examine relationship between satisfaction and organizational commitment among scout volunteer in Samarinda scout movement. Further, this study was conducted based on Galindo-Kuhn and Guzley (2001) recommendation that was to examine relationship in term of these two variables namely satisfaction and organizational commitment. The focus subject of the study was scout volunteer since it related to non formal education for youth as well as related to extension education area. Therefore, the finding of this research might have different result with others study in nonprofit organization types.

\section{Materials and Methods}

The present research used quantitative correlational research design to conduct the study. The target population of the study was scout volunteer who engaged themselves into scout movement organization center in Samarinda-East Kalimantan. Pilot studly was done priory before the actual data collection conducted to test the reliability. Meanwhile, cronbach alpha for overall variables after pilot study done priory reached $\geq .70$; organizational support and group integration (.72), participation efficacy (.74), empowerment (.79), overall satisfaction (.82), organizational commitment (.77). For real data collection, the sample was taken by using simple random sampling which calculated by Slovin Formula. The total population was 437 volunteer who engaged themselves in scout movement organization in Samarinda city. After sampling measurement only 209 samples that should be used for data analysis. However, to keep away from the outlier answer and another case, it was decided to take 220 samples for data collection. The instrument was self administered questionnaire and it comprised three sections namely 6 items of demographic which adapted from Miller and Salkind (2002), 19 items of VSI adapted from Galindo-Kuhn and Guzley (2001) with 7 likert point scale from 1 for extremely dissatisfied to 7 for extremely satisfied, and 12 items of OCQ adapted from Mowday et al., (1979) with 7 point likert scale from 1 for extremely disagreed to 7 for extremely agreed. Therefore, the total items within the questionnaire were 67 items. However, from the total samples involved, only 207 (94\%) sample which able to be processed while 13 samples $(6 \%)$ considered outlier and incomplete answer. Since it was quantitative, the data was analyzed by using descriptive and inferential statistic. 


\section{Result and Discussion}

According to descriptive statistic result, dominantly scout volunteer were male $(60.9 \%)$ prefer to female volunteer (39.1\%), majority of them were in 21 to 25 years old $(41 \%)$ and few volunteer in 41 to 47 years old $(0.5 \%)$ whereby majority of them were considered as senior scout volunteer. Moreover, commonly volunteer were still in single status $(52.7 \%)$ while only 2 people (1\%) were divorced. According to education background, majority volunteer were or in undergraduate level $(41.1 \%)$, senior high school $(36.7 \%)$ whereas few number from post graduate $(6.8 \%)$. 71 volunteer have $\leq 1$ year length involvement in scout volunteer or around 12 month involvement within the organization $(34.3 \%)$ oppositely $\geq 10$ years length involvement fulfilled by only 5 volunteer $(2.4 \%)$. Generally, their frequencies in a month were 4 times meeting (48.3\%) while more than 4 times frequency involvement in a month considered rare $(15 \%)$.

Further, the correlation coefficient between satisfaction, and organizational commitment was measured as inferential statistic. Considering that overall data was in mormal distribution, parametric statistic was employed. Therefore, Pearson Product Moment Correlation is being chosen to ensure the relationship within variables. Moreover, the result indicated there was a small positive correlation between overall satisfaction and organizational commitment ( $\mathrm{r}$ $=.298, \mathrm{p}<.00$ ). Further, it has been conducted analysis for four dimension of VSI. As a result (see Table 1), there was positive correlation between organizational support and organizational commitment $(\mathrm{r}=.314, \mathrm{p}<.05)$ as well as group integration and organizational commitment $(\mathrm{r}=.280, \mathrm{p}<.05)$. Unfortunately, participation efficacy $(\mathrm{r}=.137)$, empowerment $(\mathrm{r}=.095)$ having more than .05 value significant level (see Table 1). Therefore it can be revealed that both of those dimensions were failed to get correlation towards organizational commitment under Mowday approach (see Table 1). According the finding, these positive correlations indicated that the scout volunteer who was more satisfied in term of support given and group integration were having more committed to the organization. However, the results have weak significant correlation among overall satisfaction as well as the dimension.

Table 1. Pearson Correlation Product Moment Correlations

\begin{tabular}{lll}
\hline Variables & $\mathrm{r}$ & $\mathrm{P}$ \\
\hline Organizational support & $.314^{* *}$ & .00 \\
Participation efficacy & $.137^{*}$ & .049 \\
Empowerment & .095 & .173 \\
Group integration & $.280^{* *}$ & .00 \\
Overall satisfaction & $.298^{* *}$ & .00 \\
\hline \multicolumn{2}{c}{$* *$ Correlation is significant at the .01 level (2 tailed) }
\end{tabular}

The finding also indicated that organizational support has highest contribution to satisfaction compared to other dimensions, whereas the empowerment and participation efficacy were not important and not strengthen their job satisfaction for organizational commitment among scout volunteer. In this case, previous study (Galindo-Kuhn \& Guzley, 2001) analyzed VSI 
with intent to remain rather than using OCQ. Consequently, there is no similar result from the previous studies to support. However, according to their study, overall dimension has positive significant relationship with intent to remain. Whereas in part of empowerment and organizational efficacy of the current study showed that there was no significant relationship between them towards organizational commitment. It might be due to the different context as well as circumstance of organization causes not overall dimension having relation with organizational commitment.

\section{Conclusion}

The findings reported that there was small level relationship within satisfaction in term of organizational support and group integration. It was probably due to the training or encouragement carried out decided volunteer to find their level of satisfaction. Moreover, the function of organizational support and group integration from other staff might increasing their satisfaction (Cyr \& Dowrick, 1991). In other words, organizational commitment within scout volunteer in East Kalimantan permitted only these dimensions (organizational support and group integration) to fulfill their satisfaction thus it gives big influence to their organizational commitment.

However, present study has contribution for body of knowledge. It was able to be used as reference within nonprofit organization especially for volunteer in non formal education or extension education field since majority studies prefer to be interested in profit organization for profitable sector rather than concern on non formal learning. However, there were several limitations emerged due to the data were collected from a specific volunteer organization therefore it could not be generalized. Another implication was given to the practice within organization especially for nonprofit organization. Nonprofit area especially scout movement should make as effort to positively provide impact to the volunteer in term of their satisfaction such as carrying out a gathering event in order to force their support between themselves, improving group organization by having more interaction within organization. Moreover, stakeholder should comprehends and realizes how much inter-correlation between satisfaction and organizational commitment thus they are able to determine how to assist each volunteer to increase their involvement into organization in order to have long services. This become serious issue, considering that volunteer is also become one important element in NFE as well as in extension area. Moreover, those elements cannot be disconnected, there was influence between them. In other words, NFE or extension education system should realize that they get benefit from the volunteer involvement to conduct their program and to maintain the organization's life. Therefore, NFE or extension elements have to be able to develop and built a good relationship thus it can maintain, include as well as recruit as many as volunteers in it. Training and managing is also important to strengthen their involvement thus they have good quality in term of their organizational commitment.

Besides implication, this present study provided recommendation for practice and future research. Practically from nonprofit organization linkage with job satisfaction, it is suggested to adopt as well as adapt volunteer satisfaction index from Galindo-Kuhn and Guzley (2001) to measure the level of satisfaction rather than utilized common approach that usually being 
purposed for profit organization which directly have different character with volunteer in nonprofit organization. Since this instrument was relatively young, thus it is required to be measured in different context to get general validation. Another advantage of this instrument was made specifically for measuring volunteer for nonprofit organization. Meanwhile, OCQ from Mowday et al. (1979) was adapted to measure organizational commitment in the present study. Therefore, it is suggested to establish specific instrument which can be used for measuring organizational commitment among nonprofit organization sector since majority studies in profit organization area used OCQ. Further, future study is suggested to develop large area and sampling in order to make comparison in finding with the present study. In addition, present study only used two variables: satisfaction and organizational commitment, therefore future research is suggested to expand the objectives such as determination according to demographic part in term of their relationship between job satisfaction and organizational commitment among volunteer. Finally future research is suggested to enlarge another volunteer organization which also related to activity outside the school institution thus it would be expected having more contribution to NFE or extension education field.

\section{References}

Bang, H., Ross, S., \& Reio, T. G. (2013). From motivation to organizational commitment of volunteers in non-profit sport organizations: The role of job satisfaction. Journal of Development Management, 32(1), 96-112. http://dx.doi.org/10.1108/02621711311287044

Boyd, B. L. (2003). Identifying copetences for volunteer administration for the coming decade: A Delphi study. Journal of Agricultural Education, 44(4), 47-56. http://dx.doi.org/10.5032/jae.2003.04047

Chacon, F., Vecina, M. L., \& Davila, M. C. (2007). The Three-Stage Model of Volunteers' Duration of Service. Social Behavior and Personality, 35(5), 627-642. http://dx.doi.org/10.2224/sbp.2007.35.5.627

Cnaan, R. A., \& Goldberg-Glen, R. S. (1991). Measuring motivations to volunteer in human services. Journal of Applied Behavioral Science, 27, 269-284. http://dx.doi.org/10.1177/0021886391273003

Cyr, C., \& Dowrick, P. W. (1991). Burnout in crisisline volunteers. Administration and Policy in Mental Health, 18(5), 343-354.

Davila, M. C. L., \& Cachon, F. (2003). Adaptation de instrumentos para la evaluacion de aspectos organizacionales en ONG's in Davila et al. (2010). Organizational commitment in Spanish and italian Volunteers: A comparative study. Revista de Psicologia Del Trabajo Y de Las Organizaciones, 19(2), 159-179.

Dorsch, K. D., Riemer, H. A., Sluth, V., \& Paskevich, D. M. (2002). What Affects A Volunter's Commitment? What Affects a Volunteer 's Commitment? Canadian Centre for Phylanthropy, 1-8.

Ellis, S. J., \& Noyes, K. H. (1990). By the people: A history of Americans as volunteers (p. 432). San Fransisco: Jossey-bass Publishers. Retrieved from 
http://trove.nla.gov.au/version/20814254

Field, D., \& Johnson, I. (1993). Satisfaction and change: A survey of volunteers in a hospice organization. Social Science Medicine, 36, 1625-1633. http://dx.doi.org/10.1016/0277-9536(93)90351-4

Galindo-Kuhn, R., \& Guzley, R. M. (2001). Journal of Social Service The Volunteer Satisfaction Index The Volunteer Satisfaction Index : Construct Definition, Measurement , Development, and Validation. Journal of Social Service Research, 37-41.

Gidron, B. (1983). Sourcesof job satisfaction among service volunteers. Journal Voluntary Action Research, 12, 20-35.

Harootyan, R. A. (1996). Volunteer activity by older adults. In J. E Birren (Ed.). Encyclopedia of Gerontology: Age, aging, and the aged (Vol. 2). San Diego: Academic Press. p. $613-620$

Hartenian, L. S. (2007). Nonprofit agency dependence on direct service and indirect support volunteers: An empirical investigation. Nonprofit Management and Leadership, 17(3), 319-334. http://dx.doi.org/10.1002/nml.152

Mathieu, J. E., \& Zajac, D. M. (1990). A review and meta-analysis of the antecedents, correlates, and consequences of organizational commitment. Psychological Bulletin, 108(2), 171-194. http://dx.doi.org/10.1037/0033-2909.108.2.171

Merriam, S. B., \& Cafarrella, R. S. (1999). Learning in Adulthood (2nd ed.). San Fransisco: Jossey-Bass.

Meyer, J. P., \& Allen, N. J. (1997). Commitment in the Workplace: Theory, Research, and Application. Sage Publications, Thousands Oak, CA, USA, ISBN 9780761901051, 150.

Meyer, J. P., \& Herscovitch, L. (2001). Commitment in the workplace: toward a general model. Human Resource Management Review, 11(3), 299-326. http://dx.doi.org/10.1016/S1053-4822(00)00053-X

Miller, D. C., \& Salkind, N. J. (2002). Handbook of Research Design and Social Measurement. London: Thousand Oaks: Sage Publication.

Mowday, R. T., Steers, R. M., \& Porter, L. W. (1979). The measurement of organizational commitment. Journal of Vocational Behavior, 14(2), 224-247. http://dx.doi.org/10.1016/0001-8791(79)90072-1

Okun, M. A., \& Schultz, A. (2003). Age and motives for volunteering: testing hypotheses derived from socioemotional selectivity theory. Psychology and Aging., 18(2), 231-239. http://dx.doi.org/10.1037/0882-7974.18.2.231

Ozminkowski, R. J., Supiano, K. P., \& Campbell, R. (1991). Volunteers in nursing home enrichment: A survey to evaluate training and satisfaction. Activities, Adaptation, and Aging, 15(3), 13-43. http://dx.doi.org/10.1300/J016v15n03_02 
Pearce, J. L. (1993). Volunteers: The organizational behaviour of unpaid workers. London/New York: Routledge.

Phillips, J. J., \& Edwards, L. (2008). Managing Talent Retention: an ROI Approach (1st ed., p. 432). San Fransisco, USA: Pfeiffer.

Ping, L., Wing, W., Chui, H., \& Yuen, Y. (2011). The Volunteer Satisfaction Index: A Validation Study in the Chinese Cultural Context. Soc. Indic Res, 104, 19-32. http://dx.doi.org/10.1007/s11205-010-9715-3

Schmiesing, R., Soder, J., \& Russell, S. (2005). What Motivates Volunteers to Serve in a Youth Literacy Program? Journal of Extension Education, 43(6). Retrieved from http://www.joe.org/joe/2005december/rb4.php

Sheldon, M. E. (1971). Investments and Involvements as Mechanisms Producing Commitment to the Organization. Administrative Science Quarterly, 16(2), 143-150. http://dx.doi.org/10.2307/2391824

Siti-nazilah, M. A., Rozmi, I., \& Fauziah, I. (2012). The relationship between satisfaction and organizational commitment among undergraduate volunteer. Social Science, 7(3), 378-382.

Smith, P. C., Kendall, L. M., \& Hulin, C. L. (1969). The Measurement of Satisfaction in Work and Retirement: A Strategy for the Study of Attitudes (pp. 1-186). Rand McNally.

Snyder, M., \& Omoto, A. M. (2004). Volunters and volunteer organizations: Theoritical perspectives and practical concerns. In R. E. Reggio \& S. Smith-Orr (Eds.), Improving Leadership in Nonprofit Organization (pp. 163-179). San Fransisco: Jossey-Bass.

Steers, R. M. (1977). Antecedents and Out- comes of Organiza- tional Commitment. Administrative Science Quarterly, 22(1), 46-56. http://dx.doi.org/10.2307/2391745

Terry, B., Harder, A., \& Pracht, D. (2011). Understanding the Value of Volunteer Involvement. Journal of Agricultural Education, 52(2), 118-127. http://dx.doi.org/10.5032/jae.2011.02118

Vaske, A. (2008). The relationship between motivation to volunteer and cultural preference: A study of a youth developemnt organization. Proquest Database. St. Ambrose University.

Warsi, S., Fatima, N., \& Sahibzada, S. A. (2009). Study on relationship between organizational commitment and its determinants among private sector employees of. International Review of Business Research Papers, 5(3), 399-410.

Williamson, D. A. (1996). Job satisfaciton in social services. Social Science (p. 202). Garland Publishing.

\section{Copyright Disclaimer}

Copyright reserved by the authors.

This article is an open-access article distributed under the terms and conditions of the Creative Commons Attribution license (http://creativecommons.org/licenses/by/3.0/). 